\section{Corruption in Vietnamese Higher Education}

\section{DENNIS C. MCCORNAC}

Dennis C. McCornac is associate professor of economics at Anne Arundel Community College, 101 College Parkway, Arnold, MD, USA. E-mail: dmccornac@aacc.edu.

$\mathrm{M}$ ore than two decades have passed since Vietnam began the transition to a market economy. The policy of Doi Moi, generally translated as economic renovation, has fostered major changes in social and economic institutions and highly improved production capabilities and the standard of living. These positive developments notwithstanding, Vietnam remains a less-developed country, and many of the ills associated with this environment have not been alleviated. Corruption still plagues most sectors of the economy, and in 2007 Transparency International gave Vietnam a dismal 2.6 rating score on a scale of $\mathrm{I}$ to Io, with Io being least corrupt.

\section{Corruption in Education}

Education suffers pervasive corruption, particularly regarding student and teacher behavior. Bribes for school entrance, exams, and assessment, are just a few examples of practices in both secondary and higher education sectors. Although the issue has come under increased scrutiny by the state media and educational authorities, a review of the literature reveals very little formal research on corruption in education. This can probably be attributed to the unwillingness of both parties to provide accounts of illegal transactions and the extent to which the practices are viewed as corrupt.

\section{Research Method}

The collection of data through a formal survey instrument was not possible due to institutional constraints. Thus, informal surveys were conducted in various classes taught by the author during his teaching in Vietnam over the past decade. The sample size was approximately I50 first-year university-level undergraduate students and too first-year university graduate students. In addition, in-depth interviews were carried out with close to 35 students at various levels, I3 teachers, and 5 administrators. These in-depth interviews were conducted in a semistructured format with a heavy emphasis on open-ended questions.

\section{Norm, Rather Than Exception}

The information from students, faculty, and administrators provides clear indications that corruption in higher education in Vietnam is both rampant and institutional. Corruptive practices are the norm rather than the exception and foster an environment of distrust and suspicion on the part of those forced to participate in this system.
In the informal survey of classes, more than 95 percent of the students reported they had cheated at least once in a class, and all had observed situations of cheating by other students. Cheating is looked at as being so common that many people involved are of the opinion that not to do so puts them at a disadvantage. Social and peer pressure play a significant role in the decision to cheat, and cheating is looked at as a necessary component of the educational experience. Both students and faculty also commented that cheating is "just part of Vietnamese culture."

\section{TEACHERS AND EXAMINATIONS}

In various interviews, stories were told of corrupt practices by teachers, particularly during testing. During an examination, for example, a woman (not the supervising teacher) appeared in class and instructed the supervisor to allow one of the students to leave the examination. When the student returned he had in his possession a piece of paper, apparently given to him by the woman, containing answers to the test. The answers were also provided to other students, while the supervising teachers did nothing to stop the practice. The student who reported the story, however, stated "I felt very disappointed because I worked very hard studying for the exam, while those who did nothing and cheated received higher marks."

Faculty members admitted they were lax in carrying out procedures such as careful proctoring of examinations. Institutions either lacked strict policies to deal with these matters, or there was a general consensus that nothing should be done. Stroll down the corridor of a Vietnamese university, and it not uncommon to observe students openly talking, using cheat sheets, and blatantly copying during tests.

In the informal survey of classes, more than 95 percent of the students reported they had cheated at least once in a class, and all had observed situations of cheating by other students.

\section{THE USE OF BRIBES}

Given the low salary level of educators in Vietnam, it is often necessary for professors to engage in corrupt practices. Almost all of the faculty and administrators interviewed admitted receiving payments to give higher grades or to either assist or guarantee a student admission to a university.

A typical example was reported by one individual whose good friend passed the university entrance despite being a poor-performing student who never studied. The poor-performing student later confessed that the headmaster of the university accepted a too million dong (US\$6,200) payment from the student's father to guarantee his admission.

A number of students reported on the activities that occur on Teacher's Day, a public holiday celebrated in November 
each year. The general practice is for students to go to a teacher's house and give gifts of flowers. However, it has now become more common for the teacher to receive expensive gifts such as cell phones or designer bags, with the expectation of higher exam grades and other favors in return.

The growing economy has only exacerbated the situation as competition for employment opportunities among students has increased and faculty members have a greater need to supplement their income.

\section{CONCLUSION}

There is no doubt that the Vietnamese higher education system is in need of serious reform. Corruption is epidemic, and actions must be taken to change the environment in which these practices flourish. The recent decision by the Ministry of
Education and Training to adopt new, stricter measures on national exams and the increased media attention on corruption are steps in the right direction. The slogan for the educational reform campaign is "say no to cheating in examinations and achievement chasing in education." Nevertheless, there is not only a general frustration on all sides with the status quo but also concern that the current situation cannot be changed.

If Vietnam desires to obtain an international standard educational system, required reforms are necessary from all parties. Perhaps, most importantly, there must be a monumental change in the attitude and thinking by students, faculty, and parents. Education is a right and privilege that is earned, not a commodity to be sold by administrators and faculty.

\section{New Publications}

Aby, Stephen H., ed. The Academic Bill of Rights Debate: A Handbook. Westport, CT: Praeger, 2007. 248 pp. \$39.95 (hb). ISBN 0-275-99244-6. Web site: www. praeger .com.

Since 2003, when an "academic bill of rights" was introduced by conservative activist David Horowitz, there has been a debate in the United States about "liberal bias" in American higher education and discrimination against conservative academics. The debate has even extended to several state legislatures.

Albornoz, Orlando. La Universidad Latinoamericana: Entre Davos y Porto Alegre [The Latin American University: From Davos to Porto Alegre]. Caracas, Venezuela: Los Libros de El Nacional, 2006. Apartado Postal 209, Caracas 1010A, Venezuela.

Using two very different visions for development-the World Economic Forum and the World Social Forum-the author analyzes the role of the university in Latin American society, giving special emphasis to the case of Venezuela. Albornoz argues that a "middle point" between the extreme positions of Davos and Porto Alegre can bridge the gap between the practical demands of society and unique role of the university in national development and discourse. (Laura Rumbley)
Bogue, E. Grady. Leadership Legacy Moments: Visions and Values for Stewards of Collegiate Mission. Westport, CT: Praeger Publishers, 2007. 144 pp. \$59.95 (hb). ISBN 0-275-99778-2. Web site: www.praeger.com.

Written as a guide for senior administrators in US universities by an experienced academic administrator, this volume focuses on how leaders can build a positive legacy of their work.

Consejo Superior de Educación, ed. Educación Superior: Diversidad y Acceso [Higher Education: Diversity and Access]. Calidad en la Educación, 26 (July 2007). Santiago, Chile: Consejo Superior de Educación, Marchant Pereira 844, Providencia, Santiago, Chile.

This edition of the Chilean Higher Council on Education's biannual publication is comprised of eight monographs, three studies, and six additional articles-all addressing the issues of access and diversity in postsecondary education. The primary focus is on the Chilean context, although Bolivia, the United States, and the European Union also receive attention. Calidad en la Educación is now included in Latindex, the regional online information system for scientific journals in Latin America, the Caribbean, Spain, and Portugal. It also appears in CLASE, the database of Universidad Nacional Autónoma de México for scientific and humanities journals in Latin America and the Caribbean. (Laura Rumbley)
Jantan, Muhamad, et al., eds. Enhancing Quality of Faculty in Private Higher Education Institutions in Malaysia. Penang, Malaysia: Institut Penyelidkan Pendidikan Tinggi Negara, 2006. 187 pp. (pb). ISBN 98342662-1-9. Web site: www.usm .my /ipptn.

Almost one-third of Malaysian students attend private higher education institutions, many of which are new and considered of questionable quality. This book looks at the faculty in private higher education with the aim of understanding their working conditions and improving their quality. Analysis of faculty training, teaching conditions, and related issues is included.

Kell, Peter, and Gillian Vogl, eds. Higher Education in the Asia Pacific: Challenges for the Future. Newcastle, UK: Cambridge Scholars Publishing, 2007. 245 pp. (hb). ISBN 1-84718-191-O. Web site: www.c-sp.org.

A potpourri of themes stemming from several Australia-Malaysia conferences, this book features essays on the role of English and English-language teaching, the internationalization of higher education in Malaysia, academic governance in Malaysia, quality assurance in offshore teaching and learning, the role of academic women in Malaysia, and others. 